\title{
Training paradigms to enhance clinical observational skills in clinical practice: A scoping review
}

\author{
Modi Owied Al-Moteri ${ }^{* 1,2}$, Virginia Plummer ${ }^{2,3}$, Simon Cooper ${ }^{4,5}$, Mark Symmons ${ }^{2}$ \\ ${ }^{1}$ Nursing Department, Al-Taif University, Western region, Saudi Arabia \\ ${ }^{2}$ School of Nursing and Midwifery, Monash University, Victoria, Australia \\ ${ }^{3}$ Peninsula Health, Frankston, Australia \\ ${ }^{4}$ School of Nursing and Midwifery and healthcare, Federation University, Victoria, Australia \\ ${ }^{5}$ School of Nursing and Midwifery, Brighton University, United Kingdom
}

Received: August 9, 2015

DOI: $10.5430 /$ jnep.v5n12p96
Accepted: August 27, 2015

Online Published: September 24, 2015

URL: http://dx.doi.org/10.5430/jnep.v5n12p96

\begin{abstract}
A number of training approaches to improve the clinical observation skills of undergraduate students have been identified in the literature. Immediate improvement from such approaches on students' clinical observational skills have been documented. However, this review identified that observational skill improvements did not occur in real and complex clinical conditions where the incidence of perception failure may increase. In six out of seven approaches examined, (i) the visual attention paid by students during observation is more focused than the actual visual attention clinicians usually pay in the real clinical area; (ii) the observations were made on images of clinical cases with visible signs which allowed findings to be noticed easily and with minimal searching efforts; (iii) the improvement in observation skills was based on what was noticed rather than what was missed, hence, perceptual failure was concealed; and (iv) in evaluations, students were asked to describe "what they see", the process of describing has the possibility to increase the tendency to conflate observations with inferences, and as a result, students may have stopped searching after being satisfied with their findings. To conclude, this review showed that perception paradigms have not been acknowledged in clinical observation training approaches with a need for further research relating to visual perception in clinical settings.
\end{abstract}

Key Words: Undergraduate, Recognition, Clinical observation, Training, Deterioration, Perception failure, Scoping review, Nursing practice

\section{INTRODUCTION}

Clinical observations are a fundamental routine task assuring that clinicians are aware of the changes in a patient's health status. ${ }^{[1]}$ In contrast to observation of emergency conditions, which focus on a well known diagnosis, the patient in the ward requires "anticipatory care". This care can be achieved mainly through observing changes to a patient's condition. Early identification of significant physiological changes is es- sential in everyday patient care. ${ }^{[2]}$ Hence, good observation skills are a critical requirement for the provision of optimum and safe care. ${ }^{[3]}$

\section{Background}

According to The Oxford English Dictionary to observe is "to watch carefully and attentively, to detect, to perceive and to register it as being significant". ${ }^{4]}$ This definition encom-

\footnotetext{
*Correspondence: Modi Owied Al-Moteri; Email: moal1@student.monash.edu; Address: School of Nursing and Midwifery, Monash University, Victoria, Australia.
} 
passes two processes: (i) visual searching represents attentive watching, and (ii) perceiving is the detection and registration of some critical cue. This implies an active process in that our eyes visually target pertinent information. There is also a more passive process when we are not looking for specific cues but our attention can still be arrested should a pertinent stimulus appear in our visual field. ${ }^{[5]}$ It is critical in the case of nursing, or any other expert or specialist field, to understand what stimuli might be "pertinent"; this knowledge would often be considered important for the on-ward anticipatory care highlighted earlier.

Humans are capable of conscious and unconscious perception of the environment and studies have shown a failure to notice or respond to objects in the visual field, even though they have been specifically fixated or focused upon. ${ }^{[6]}$ This is mainly a limitation in human perception, ${ }^{[7]}$ or the processing of information to a conscious level. The odds of not "noticing" a pertinent stimulus increases when dealing with a large quantity of visual information in a cluttered or busy scene in which many details compete for attention. Attention capacity is limited as there is a single pool of mental capacity that can be devoted to processing the visual information. ${ }^{[8]}$ That capacity may be split or divided, but not increased. ${ }^{[9]}$ Hence, distraction, interruption, and attempts at multitasking reduce the attentional resource available for observation. ${ }^{[10]}$

Registered nurses in increasingly complex acute care settings are often faced with interruptions and distractions in their daily work. ${ }^{[11]}$ In a typical general ward nurses are often in charge of five or more patients, each with a different constellation of signs and symptoms and underlying illnesses. ${ }^{[12,13]}$ These competing attentional demands and irregular disruptions of focus can cause errors. ${ }^{[14]}$ However, observation capabilities can be enhanced. Hirstetal ${ }^{[15]}$ found that extensive practice can increase the ability to perform adequate observation even in complex environments. Khalifa ${ }^{[16]}$ found that the ability to detect abnormalities in a complex panoramic x-ray image could be improved amongst novice dentists with training in visual skills. Similar findings that such training was useful were also reached by Litchfield et al. ${ }^{[17]}$ with the most effective training being undertaken during the early stages of learning.

There are various training strategies to teach or improve clinical observation skills present in literature. ${ }^{[18]}$ While some of these approaches have reported an immediate improvement in students' clinical observation skills, the transferability of this improvement to the authentic clinical environment is questionable, ${ }^{[19]}$ since considerable studies report cases of clinical observation lapses. An example is the failure of nurses to recognize the deteriorating patient in the general

Published by Sciedu Press ward, despite the patient having been assessed by nurses, and the presence of clinical evidence up to 24 hours prior to deterioration. ${ }^{[20]}$ Another example is what Henneman, et $a l .{ }^{[21]}$ noticed when assessing the ability of health providers to notice the error in patient ID bands: some health providers did look at the ID band but failed to detect the error. The previous examples and many others indicate that observation is at risk by the inability of the clinician to notice important data while providing care.

In cognitive psychology, failure to notice a fully visible visual item that is in direct view indicates "failure in perception", ${ }^{[6]}$ which has been offered as an explanation for critical lapses in observation in various contexts. The recognition of the role of perception in relation to the teaching of clinical observation skills has been acknowledged. In this regard, Boudreau, Bleakley and Bardes have stressed the importance of the perception aspect in clinical observation and recommend training approaches where the perception aspect is addressed. ${ }^{[19,22,23]}$ To what extent these recommendations were acknowledged when designing training approaches for improving observation skills is unknown, and this is the scope of this review.

\section{METHOD}

\section{Scoping review framework}

A comprehensive systemic search of the main sources of evidence to identify papers dedicated to the exploration of visual training for nurses was undertaken based on predefined searching criteria. The review was conducted in line with the Arksey and O'Malley ${ }^{[24]}$ framework. The framework is appropriate when an area is complex or not been addressed or well-defined yet. ${ }^{[25]}$ The framework consists of five steps to conduct a scoping review: formulate the review question; search for relevant studies; select the potential studies; chart the data; summarize and report the findings.

\section{Aim}

This review aimed to search the literature to identify the available training approaches designed to enhance undergraduate clinical observational skills. The following review questions were formulated and addressed: what are the training approaches available in the literature to improve undergraduate clinical observation skills? When demonstrating the impact of the training approaches on students' observational skills, has observation performance been evaluated under conditions that mimic the complexity of the clinical setting where the incidence of perception limitations may increase?

\section{Search strategies}

The search process targeted studies that (1) were conducted in undergraduate clinical education; (2) implemented a train- 
ing strategy for improving observation skills; (3) were published in English after 2005, irrespective of whether they were peer reviewed or not, but they must have been indexed by at least "Google Scholar". Although peer reviewed papers are preferred for most systematic searching reviews, important non-peer reviewed papers may be missed. This is in essence a scoping review, as distinguished from other types of systematic review. ${ }^{[26]}$ Studies that aimed to improve students' inferences and mental activities alike such as decision making, problem solving and clinical reasoning were excluded. Three databases - ProQuest, Ovid, and PubMed - were searched, as well as Google Scholar. PubMed is the biomedical leading citation database. ${ }^{[26]}$ Ovid as a search engine, can access multiple databases including MEDLINE, PsycINFO, PreMEDLINE, EBM, Cochrane Database, Cancerlit, CINAHL, and EMBASE ${ }^{[27]}$ hence, ensuring a wide range of literature coverage. Though, Ovid and PubMed share the access to MEDLINE, new references are added to PubMed more quickly than they are to MEDLINE. [27]

Initially, several trials using broad primary searching terms were used before settling on a combination of concise primary search terms - "training" AND "recognition" AND "clinical observation" AND "undergraduate". Five potential papers were identified. Among the five papers, Braverman ${ }^{[28]}$ was found to be the most relevant paper; hence, through using a PubMed related citation feature 65 similar articles were found. From the 65, several papers were identified as potentially relevant; the relevant papers related key words and word synonyms that were used to expand the searching process. As shown in Figure 1, the second search across the 3 databases and Google Scholar resulted in a total of 1,551 hits, and after screening all titles and abstracts, 1,505 papers were removed.

\section{Select the potentially relevant papers and chart the data}

Given that the authors of this review were only interested in the training strategies for clinical observation, no attempt was made to evaluate the methodological quality or level of evidence of the included studies. As shown in Figure 1, forty-six studies were screened for eligibility based on the inclusion criteria, then twenty four studies were fully reviewed in which the following information was charted: participants, purpose, training strategies, and training outcomes. Out of the twenty-four papers, seven were then included in the final review (see Table 1 ).
Preliminary search

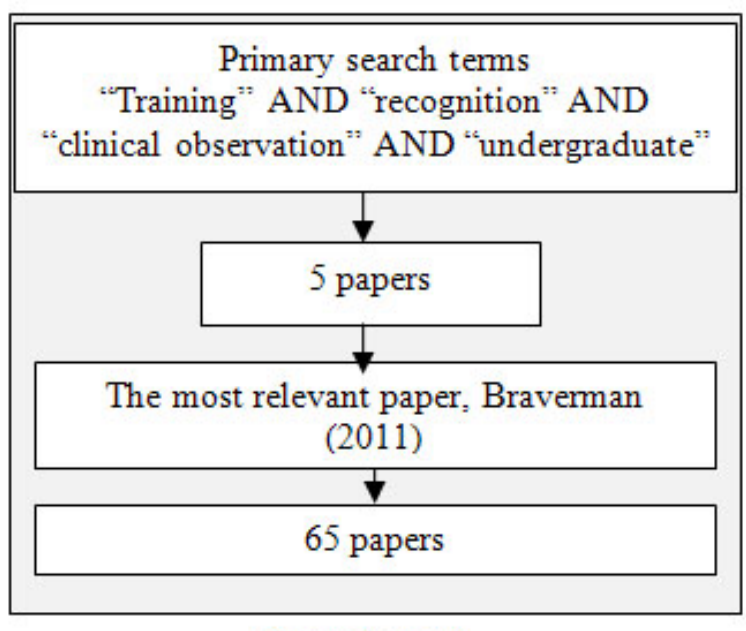

Second search

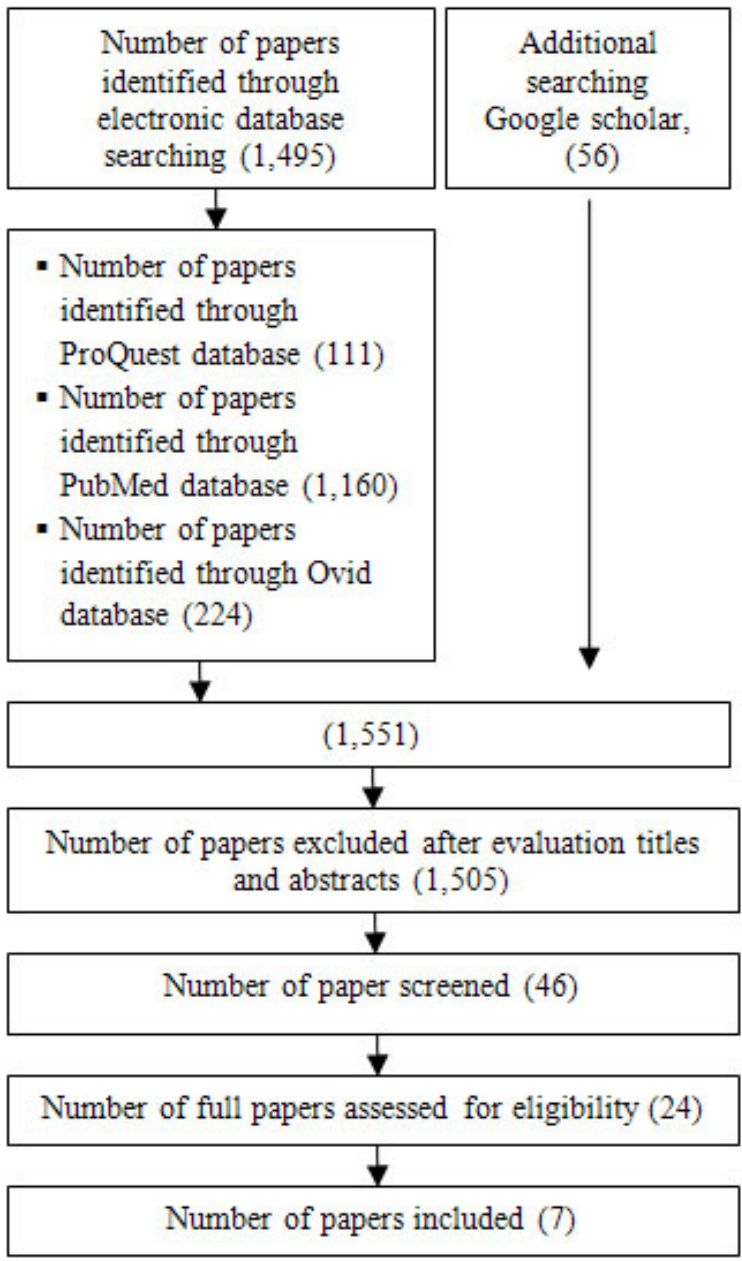

Figure 1. Flow diagram of the study selection process 
Table 1. Techniques and methods to demonstrate the impact of the training approaches on students' observational skills

\begin{tabular}{|c|c|c|c|c|c|c|}
\hline \multirow{2}{*}{$\begin{array}{l}\text { Author(s)/ } \\
\text { Date }\end{array}$} & \multirow{2}{*}{$\begin{array}{l}\text { Partici- } \\
\text { pants }\end{array}$} & \multirow[b]{2}{*}{ Purpose } & \multirow[b]{2}{*}{ Approach } & \multicolumn{3}{|l|}{ Evaluation } \\
\hline & & & & Visual display & Task & $\begin{array}{l}\text { Evaluation } \\
\text { technique }\end{array}$ \\
\hline $\begin{array}{l}\text { Klugman et } \\
\text { al. }^{[29]}\end{array}$ & $\begin{array}{l}32 \text { medical } \\
\text { and nursing } \\
\text { students }\end{array}$ & $\begin{array}{l}\text { To evaluate whether } \\
\text { students' exposure to visual } \\
\text { thinking strategies (VTS) } \\
\text { would improve their physical } \\
\text { observation skills and } \\
\text { increase tolerance for } \\
\text { ambiguity }\end{array}$ & $\begin{array}{l}\text { Visual } \\
\text { thinking } \\
\text { strateg }\end{array}$ & $\begin{array}{l}\text { Static: } 3 \\
\text { images of } \\
\text { works of art } \\
\text { and } 3 \text { images } \\
\text { of patients }\end{array}$ & $\begin{array}{l}\text { Students gave free-response } \\
\text { answers to the question "What do } \\
\text { you see?” for the stimuli. Patient } \\
\text { images were headshots taken in a } \\
\text { dermatology clinic of patients } \\
\text { who had visible signs of their } \\
\text { disease, including examples of } \\
\text { lupus, rosacea, alopecia, and } \\
\text { thyroid goitre }\end{array}$ & $\begin{array}{l}\text { Number of words } \\
\text { and number of } \\
\text { observations were } \\
\text { counted }\end{array}$ \\
\hline $\begin{array}{l}\text { Jarodzka et } \\
\text { al. }^{[30]}\end{array}$ & $\begin{array}{l}60 \text { medical } \\
\text { students }\end{array}$ & $\begin{array}{l}\text { To explore whether visually } \\
\text { cueing relevant information } \\
\text { in Case Videos of Patients } \\
\text { (CVPs) in different modes } \\
\text { with eye-movement } \\
\text { modelling examples } \\
\text { (EMMEs) could improve } \\
\text { clinical reasoning based on } \\
\text { visual observations. }\end{array}$ & $\begin{array}{l}\text { Visual } \\
\text { reinforce- } \\
\text { ment }\end{array}$ & $\begin{array}{l}\text { Dynamic:3 } \\
\text { Case videos of } \\
\text { patients }\end{array}$ & $\begin{array}{l}\text { Participants were shown three } \\
\text { new CVPs without verbal } \\
\text { explanations or eye-movement } \\
\text { replays for a mean duration of } \\
29.67 \text { sec each. These CVPs } \\
\text { depicted different children each } \\
\text { displaying a particular seizure }\end{array}$ & $\begin{array}{l}\text { Using Eye } \\
\text { tracking, } \\
\text { identification of } \\
\text { eye fixation upon } \\
\text { area of interest } \\
\text { was obtained }\end{array}$ \\
\hline $\begin{array}{l}\text { Naghshineh } \\
\text { et al. } .^{[31]}\end{array}$ & $\begin{array}{l}24 \\
\text { pre-clinical } \\
\text { students }\end{array}$ & $\begin{array}{l}\text { To improve students' visual } \\
\text { acumen through structured } \\
\text { observation of artworks, } \\
\text { understanding of fine arts } \\
\text { concepts and applying these } \\
\text { skills to patient care }\end{array}$ & $\begin{array}{l}\text { Visual } \\
\text { literacy }\end{array}$ & $\begin{array}{l}\text { Static: } 3 \\
\text { images of } \\
\text { patients and } 2 \\
\text { images of } \\
\text { artworks }\end{array}$ & $\begin{array}{l}\text { Students were given } 8 \text { minutes to } \\
\text { report free-text observations and } \\
\text { interpretations. The clinical } \\
\text { images included physical findings } \\
\text { associated with upper extremity } \\
\text { DVT, Wallenberg syndrome, and } \\
\text { relapsing polychondritis }\end{array}$ & $\begin{array}{l}\text { Written visual } \\
\text { skill examination. } \\
\text { A "point" was } \\
\text { assigned for each } \\
\text { "accurate" } \\
\text { observation }\end{array}$ \\
\hline $\begin{array}{l}\text { Pellico et } \\
\text { al. }^{[32]}\end{array}$ & $\begin{array}{l}66 \text { nursing } \\
\text { students }\end{array}$ & $\begin{array}{l}\text { To evaluate the effects of an } \\
\text { art museum experience on } \\
\text { the observational skills of } \\
\text { nursing students }\end{array}$ & $\begin{array}{l}\text { Looking Is } \\
\text { Not Seeing } \\
\text { pedagogy }\end{array}$ & $\begin{array}{l}\text { Static: } 6 \\
\text { patient } \\
\text { photographs }\end{array}$ & $\begin{array}{l}\text { Students were given five minutes } \\
\text { to observe the patient photograph } \\
\text { and } 5 \text { minutes to record all } \\
\text { observations in writing. At the end } \\
\text { of } 5 \text { minutes of recording details, } \\
\text { students were given } 3 \text { minutes to } \\
\text { record their interpretations of the } \\
\text { clinical issue represented in the } \\
\text { picture }\end{array}$ & $\begin{array}{l}\text { Number of } \\
\text { observations, as } \\
\text { measured by the } \\
\text { written word } \\
\text { count }\end{array}$ \\
\hline $\begin{array}{l}\text { Grossman } \\
\text { et } \text { al. }^{[33]}\end{array}$ & $\begin{array}{l}19 \text { nursing } \\
\text { students }\end{array}$ & $\begin{array}{l}\text { To enhance nurse practitioner } \\
\text { students' observation and } \\
\text { reflective thinking skills } \\
\text { using Looking Is Not Seeing, } \\
\text { a reflective } \\
\text { practice/experiential learning } \\
\text { technique that uses art } \\
\text { objects to teach observation }\end{array}$ & $\begin{array}{l}\text { Looking Is } \\
\text { Not Seeing } \\
\text { pedagogy }\end{array}$ & $\begin{array}{l}\text { Static image: } \\
\text { Clinical } \\
\text { Picture } \\
\text { Assessment } \\
\text { (CPA) features } \\
\text { eight } \\
\text { photographic } \\
\text { images of } \\
\text { dermatological } \\
\text { lesions }\end{array}$ & $\begin{array}{l}\text { Students took the test, consisting } \\
\text { of timed writing of a full } \\
\text { description of the first two CPA } \\
\text { images, plus an interpretation of } \\
\text { what they observed about each }\end{array}$ & $\begin{array}{l}\text { A scoring list of } \\
\text { Possible } \\
\text { Observations and } \\
\text { Possible } \\
\text { Interpretations for } \\
\text { each image was } \\
\text { constructed }\end{array}$ \\
\hline $\begin{array}{l}\text { Jasani et } \\
\text { al. }^{[34]}\end{array}$ & $\begin{array}{l}110 \text { third } \\
\text { year medical } \\
\text { students }\end{array}$ & $\begin{array}{l}\text { To develop and teach a visual } \\
\text { arts-based exercise for } \\
\text { medical students, and to } \\
\text { evaluate its usefulness in } \\
\text { enhancing observation skills } \\
\text { in clinical diagnosis }\end{array}$ & $\begin{array}{l}\text { Visual } \\
\text { Thinking } \\
\text { Strategies }\end{array}$ & $\begin{array}{l}\text { Static image: } 2 \\
\text { patient } \\
\text { photographs }\end{array}$ & $\begin{array}{l}\text { Students examined two patient } \\
\text { photographs with visible medical } \\
\text { conditions and were asked to list } \\
\text { unique observations regarding the } \\
\text { first photograph, and to write a } \\
\text { free text description about the } \\
\text { second photograph }\end{array}$ & $\begin{array}{l}\text { Qualitative } \\
\text { analysis of free } \\
\text { text descriptions }\end{array}$ \\
\hline $\begin{array}{l}\text { Shapiro et } \\
\text { al. }^{[35]}\end{array}$ & $\begin{array}{l}38 \text { students } \\
\text { medical } \\
\text { students }\end{array}$ & $\begin{array}{l}\text { To better understand the } \\
\text { similarities and differences } \\
\text { between arts-based and } \\
\text { clinical teaching approaches } \\
\text { to convey observation and } \\
\text { pattern recognition skills }\end{array}$ & $\begin{array}{l}\text { Training the } \\
\text { clinical eye } \\
\text { and mind }\end{array}$ & $\begin{array}{l}\text { Static image: } \\
\text { patient } \\
\text { photographs }\end{array}$ & $\begin{array}{l}\text { Students looked at a series of } \\
\text { clinical pictures, systematically } \\
\text { identified details, and then } \\
\text { summarised the pattern }\end{array}$ & $\begin{array}{l}\text { Qualitative } \\
\text { examination of } \\
\text { the written } \\
\text { feedback from } \\
\text { students, } \\
\text { observations, and } \\
\text { instructor } \\
\text { debriefings }\end{array}$ \\
\hline
\end{tabular}




\section{RESULTS AND DISCUSSION}

The identified training approaches are: visual thinking strategy, ${ }^{[29,34]}$ visual reinforcement, ${ }^{[30]}$ visual literacy, ${ }^{[31]}$ Looking Is Not Seeing pedagogy ${ }^{[32,33]}$ and training the clinical eye. ${ }^{[35]}$

The training approaches follow two main types of training principles: training the eye for deep seeing and guiding the eye. Techniques that function under the principle of "training the eye for deep seeing" are "Visual Thinking Strategy", "Visual literacy", "Training the clinical eye and mind" and "Looking Is Not Seeing pedagogy". These techniques involve several training sessions in which students are exposed to a 'visual display' such as a piece of art, a painting or clinical photographs, and asked to answer "three questions to focus observations: 'What do you see?', 'What makes you say that?', and 'What else do you see?"'[34](p1327). The main aim of these kinds of techniques is to develop active, unbiased clinical observation. Interestingly, Shapiro and colleagues ${ }^{[35]}$ investigated training the clinical eye when using art based sessions and when using clinical image based sessions, and they found that the clinical sessions positively enhanced the diagnosis, while the arts-based sessions enhanced the emotion toward the patient. Guiding the eye, on the other hand, has used technique such as visual reinforcement. Students were shown a patient video-recording about a patient who is displaying abnormal clinical signs. Through utilizing spotlight display, clinical signs were marked while the other areas were blurred. The spotlight guides the students' eye throughout the video. The basic principle behind visual reinforcement technique is the mimicking of human visual perception.

Two main types of visual displays were used to evaluate the impact of training approaches on clinical observation: clinical images and videos. Out of the seven studies, six used a static display of patient images ${ }^{[29,31-35]}$ and improvements were then reported when there was an increase in the number of details provided by the participant, the number of words used by the student to describe the image, and the number of accurate observations made. ${ }^{[29,31-35]}$ Jarodzka et al. ${ }^{[30]}$ reported improvement in students' ability to visually search for clues and interpret the findings (see Table 1). It appeared that the evaluation was conducted immediately after finishing the training sessions and there was no follow up to evaluate if these improvements were consistently transferred to the authentic practice. It is worth noting, however, that some of the observed improvements were beyond clinical observation skills, such as improvements in emotional recognition, ${ }^{[35]}$ inter-professional team interactions, ${ }^{[29]}$ a more sophisticated level of descriptions, ${ }^{[31]}$ and improvement in the clinical reasoning. ${ }^{[30]}$ Because these improvements were outside the scope of this review, we have made no attempt to include these in the discussion.

\subsection{Demonstrating the impact of the training ap- proaches}

Observation in the ward may include observing unexpected or none salient changes in a patient's condition which create a challenge on the perceptual level of observation. ${ }^{[15]}$ Given that visual attention, visual search and visual task are the main elements of visual perception, ${ }^{[35]}$ demonstrating the impact of the identified approaches towards visual training is being addressed from this visual perception perspective.

\subsubsection{Visual attention}

The role of distraction on visual performance has been widely acknowledged by cognitive psychologists where the influence of visual attention on perception has been assessed by manipulating the amount of external distraction added and measuring visual performance. ${ }^{[36]}$ Distraction tends to reduce the amount of attention necessary to make observations. In the selected visual training approaches evaluating the impact of training on clinical observation, students were asked to search for any observations over a specific period of time, usually using a static patient's image. ${ }^{[29,31-35]}$ The visual attention paid by students during the observation is more focused than the actual visual attention clinicians usually pay in a real clinical area. Using focussed attention on a static image allows localizing and concentrating on visual transients in a particular scene, making cues easily detectable with minimum perceptual efforts. ${ }^{[10]}$ Hence, any flaw in observation will not be assessed or identified. Indeed, such flaws have been documented in patient deterioration related literature. ${ }^{[1,20,37]}$ Gunning and Fors ${ }^{[38]}$ found that when applying time pressure conditions to medical students as they assess a patient, students tend to follow a rapid guessing approach, indicating their inability to work safely under distracting conditions causing these authors to raise concern about the current structure of the medical education curriculum. Rensink ${ }^{[6]}$ has suggested techniques that can help to assess the degree to which perceptual flaw can occur while performing an observation task, one of which is to perform the observation while engaging in a secondary task. Evidently, the concurrent tasks tend to slow down detection of visual cues. ${ }^{[38]}$ Another technique is to frequently interrupt the observer during the observation task. Both techniques are believed to be more representative of conditions in everyday clinical work. ${ }^{[14]}$ Failure to observe clinical cues is more likely to occur under distraction and interruption conditions. ${ }^{[6,10]}$ 


\subsubsection{Visual search}

In a typical visual search, where the observer tends to search for and detect visual targets in a particular visual display, this search is more likely to deteriorate when the target of interest is not obvious. ${ }^{[35]}$ Clinical images in the selected studies attempted to have visible cues, ${ }^{[29,34]}$ hence, targets of interest will be noticed easily with minimal searching efforts ${ }^{[10]}$ whereas in authentic clinical areas cues may be hidden and some may be unpredictable. In light of such limitations, Boudreau et al. ${ }^{[19]}$ asserted that effective observation is basically made over a period of time and not over one static visual shot. During this period, in an authentic clinical area, the patient's clinical status may change as the case progresses, and new signs may appear, increasing the probability of a failure to notice these physiological changes. This idea was also supported by studies undertaken by cognitive psychologists, who assert that it is exactly under conditions of changeability, visibility and unpredictability that significant signs are most likely to go unnoticed. ${ }^{[6,7]}$ Hence, an appropriate visual display has a strong impact on the clinician's visual search and noticing mechanism ${ }^{[38]}$ and accordingly on decision-making and performance. ${ }^{[41]}$ Perhaps utilizing simulation that (i) represents a "true" demonstration of patient states, while (ii) allowing the student to perform overt actions, and (iii) perceiving different types of perceptual stimulus e.g., visual, auditory and kinaesthetic, is recommended. Bogossian et $a l .{ }^{[42]}$ utilized this kind of simulation for evaluating nurses' ability to notice deterioration cues, and they revealed that third year undergraduate nursing students show difficulty in recognising patient deterioration signs.

\subsubsection{Visual task}

Visual tasks need to be designed to allow measurement of perception by evaluating the observer's ability to filter out fine details and notice important information. ${ }^{[36]}$ Determination of the improvement of the observation skills in the selected training approaches was mainly made through counting either the number of findings or the number of words that have been written by students. ${ }^{[29,31,32]}$ Further descriptions by students have also been used to assess improvement in clinical observation skills, ${ }^{[34,35]}$ where students were required to present as much written detail as they could in describing their observations. These techniques do not help to adequately assess the real state of student perception as the small details here are a critical part of the evaluation. Further, these techniques focus on the noticed instead of the unnoticed observations, and therefore perceptual failure is concealed. For instance, asking students to provide a detailed description can make them vulnerable to blend their primary findings with their inferences. ${ }^{[19]}$ Observation and inferences are two distinct mechanisms; the first is the result of perceiv- ing visual cues at the awareness level for recognition, while the second relates to the processing of information at the cognitive level for decision making. ${ }^{[19]}$

Inference, per se, is critical to making a decision, ${ }^{[31]}$ but caution must be taken by students to not reach rapid inferences, by stopping further searching and being satisfied with what they have observed. Significant observations can be missed in this case and this kind of rapid inference or the so called "Osler's Error of inference" should be avoided. ${ }^{[43]}$ Shapiro ${ }^{[35]}$ was aware of such risk and strongly instructed the students to not quickly reach a diagnosis. The technique used by Jarodzka et al. ${ }^{[30]}$ maybe the most reliable to assess perception and therefore the accurate impact of training approaches. The technique used eye fixation location to assess the improvement in students' abilities to perceive the early signs of a seizure.

\subsection{General discussion}

This review aimed to search the literature to identify the available training approaches designed to enhance undergraduate clinical observational skills with a focus visual perception. The aforementioned results have clearly shown that the perceptual aspect was not acknowledged in the selected training approaches. Using methods such as images of clinical cases with visible clinical signs and asking students to describe their observations or "what they see" do not provide a true perceptual challenge, hence the perceptual status of the students was unknown. Given that no study has attempted to conduct follow-up, no evidence can be provided that this improvement has a potential effect on overcoming perception limitation in a real clinical setting.

It is crucial that when clinical observation skills are taught to undergraduate students that the underpinning perception process is considered as well. Clinical instructors need to be aware of the role of perception on the long-term learning outcomes. The clinical instructor could use a cueing paradigm, in which students are shown patient cases with cues. Cues in patient cases refer to clinical signs and must be identified by the clinical instructor prior to any intervention. The cueing paradigm is highly acknowledged by cognitive psychologists in learning as it allows researchers to assess the perceptual aspect of observation under three conditions: when attention identifies the cue, misses the cue, or splits as a result of distraction. ${ }^{[36]}$ In this review it is recommended that the technique used by Jarodzka et al. ${ }^{[30]}$ be applied in an investigation of cues in complex visual display such as patient case video, which allow for the observation of cues to be challenged by the complexity of the display.

There are various sophisticated training and assessment meth- 
ods currently available for use in medical education of which perception is the main principle of their design. For example, the eye tracking method is used extensively for perceptual training and for evaluation of training outcomes in medical image perception. ${ }^{[17]}$ In our review Jarodzka et al. ${ }^{[30]}$ used the eye tracking technique for the purpose of improving the noticing of seizures signs in a video recording of a patient case. Evidence for improvement of observational skills in this study was reported; however, this improvement may be attributed to the focus of the study on the precise visual task, of just "seizures signs".

\section{IMPLICATIONS FOR PRACTICE/EDUCATION AND RESEARCH}

Despite the fact that this review does not provide sufficient evidence to recommend changes to clinical practice and despite a lack of evidence in the medical literature supporting the role of visual perception in clinical observation, the perception paradigm in clinical observation must be taken into consideration. This should be based on the most up-to-date evidence relating to situation awareness, distraction and interruption and should include analyses of clinical observation skills in a variety of attention disruption environments.

\section{Conclusion}

This review underlines the need to consider perception when teaching and evaluating observation skills, which currently does not seem to be a priority focus of clinical training. Researchers need to investigate the observation performance under real and complex clinical conditions where the incidence of perception limitations may increase. The quality of the studies was outside the scope of this review.

\section{CONFLiCTS OF INTEREST Disclosure}

The authors declare that they have no conflicts of interest.

\section{REFERENCES}

[1] Thompson R. Safer Care for the Acutely Ill patient: learning from serious incidents, fifth report from the Patient Safety Observatory. National Patient Safety Agency (NPSA).

[2] Armitage M, Eddleston J, Stokes T. NICE guidelines: Recognising and responding to acute illness in adults in hospital: Summary of NICE guidance. BMJ: British Medical Journal. 2007; 335(7613): 258. PMid:17673769 http://dx.doi.org/10.1136/bmj . 39272 .679688 .47

[3] Currey J, Botti M. Naturalistic decision making: a model to overcome methodological challenges in the study of critical care nurses' decision making about patients' hemodynamic status. American Journal of Critical Care. 2003; 12(3): 206-211. Available from: http://ajcc.aacnjournals.org.ezproxy.lib.mona sh.edu.au/content/12/3/206. short PMid:12751394

[4] Observe. 2015 Oxford University Press. Available from: http: //ww w.oxforddictionaries.com/definition/english/observe

[5] Chun MM, Wolfe JM. The Blackwell Handbook of Sensation and Perception. John Wiley \& Sons; 2008. Chapter 9, Visual Attention; 273300. Available from: https://books.google.com.au/books

[6] Rensink RA. Attention: Change blindness and inattentional blindness. Encyclopedia of Consciousness. 2009; 1: 47-59. Available from: http://www2.psych.ubc.ca/ rensink/publication s/download/taxonomy-rr.pdf

[7] Alvarez GA, Cavanagh P. The capacity of visual short-term memory is set both by visual information load and by number of objects. Psychological Science. 2004; 15(2): 106-111. PMid:14738517 http: //dx.doi.org/10.1111/j.0963-7214.2004.01502006.x

[8] Luck SJ, Hillyard SA, Mouloua M, et al. Mechanisms of visual-spatial attention: Resource allocation or uncertainty reduction? Journal of Experimental Psychology: Human Perception and Performance. 1996; 22(3): 725. PMid:8666960 http://dx.doi.org/1 $0.1037 / 0096-1523.22 .3 .725$

[9] Di Lollo V, Smilek D, Kawahara JI, et al. System reconfiguration, not resource depletion, determines the efficiency of visual search. Perception \& psychophysics. 2005; 67(6): 1080-1087. http: //dx.doi.org/10.3758/BF03193633

[10] Durlach PJ. Change blindness and its implications for complex monitoring and control systems design and operator training. $\mathrm{Hu}-$ man-Computer Interaction. 2004; 19(4): 423-451. http://dx.doi .org/10.1207/s15327051hci1904_10

[11] Potter P, Wolf L, Boxerman S, et al. Understanding the cognitive work of nursing in the acute care environment. Journal of Nursing Administration. 2005; 35(7-8): 327-335. http://dx.doi.org/10. 1097/00005110-200507000-00004

[12] Ebright PR, Patterson ES, Chalko BA, et al. Understanding the complexity of registered nurse work in acute care settings. Journal of Nursing Administration. 2003; 33(12): 630-638. PMid:14665827 http://dx.doi.org/10.1097/00005110-200312000-00004

[13] Kalisch BJ, Aebersold M. Interruptions and multitasking in nursing care. Joint Commission Journal on Quality and Patient Safety. 2010; 36(3): 126-132. PMid:20235414

[14] Grundgeiger T, Sanderson P, MacDougall HG, et al. Interruption management in the intensive care unit: Predicting resumption times and assessing distributed support. Journal of Experimental Psychology: Applied. 2010; 16(4): 317. http://dx.doi.org/10.1037 /a0021912

[15] Hirst W, Spelke ES, Reaves CC, et al. Dividing attention without alternation or automaticity. Journal of Experimental Psychology: General. 1980; 109(1): 98. http://dx.doi.org/10.1037/009 $6-3445.109 .1 .98$

[16] Khalifa H. The Effectiveness of Systematic Search Strategy Training for the Analysis of Panoramic Images. [dissertation]. University of Toronto; 2013. Available from: http://hdl . handle.net/1807/ 42981

[17] Litchfield D, Ball LJ, Donovan T, et al. Viewing another person's eye movements improves identification of pulmonary nodules in chest $\mathrm{X}$ ray inspection. Journal of Experimental Psychology: Applied. 2010; 16(3): 251. http://dx.doi.org/10.1037/a0020082 
[18] Ousager J, Johannessen H. Humanities in undergraduate medical education: a literature review. Academic Medicine. 2010; 85(6): 988-998. PMid:20505399 http://dx.doi .org/10.1097/ACM . 0 b013e3181dd226b

[19] Boudreau JD, Cassell EJ, Fuks A. Preparing medical students to become skilled at clinical observation. Medical Teacher. 2008; 30(910): 857-862. PMid:18825545 http://dx .doi.org/10.1080/0 1421590802331446

[20] Beaumont K, Luettel D, Thomson R. Deterioration in hospital patients: early signs and appropriate actions. Nursing Standard. 2008; 23(1): 43. Available from: http://search.proquest. com.ezproxy.lib.monash.edu .au/docview/219875165?accountid=12528 PMid:18814476 http://dx.doi.org/10.7748/ns2008.09.23.1.43.c6653

[21] Henneman PL, Fisher DL, Henneman EA, et al. Patient identification errors are common in a simulated setting. Annals of Emergency Medicine. 2010; 55(6): 503-509. PMid:20031263 http: //dx.doi.org/10.1016/j.annemergmed.2009.11.017

[22] Bleakley A, Farrow R, Gould D, et al. Making sense of clinical reasoning: judgement and the evidence of the senses. Medical Education. 2003; 37(6): 544-552. http://dx.doi.org/10.1046/j.1365-2 923.2003.01542.x

[23] Bardes CL, Gillers D, Herman AE. Learning to look: developing clinical observational skills at an art museum. Medical Education. 2001; 35(12): 1157-1161. http://dx.doi.org/10.1046/j.136 5-2923.2001.01088.x

[24] Arksey H, O’Malley L. Scoping studies: towards a methodological framework. International Journal of Social Research Methodology. 2005; 8(1): 19-32. http://dx.doi.org/10.1080/13645570320 00119616

[25] Wilson MG, Lavis JN, Guta A. Community-based organizations in the health sector: a scoping review. Health Res Policy Syst. 2012; 10(36): 101186. Available from: http://www.biomedcentral. com/content/pdf/1478-4505-10-36.pdf http://dx.doi.o $\mathrm{rg} / 10.1186 / 1478-4505-10-36$

[26] Armstrong R, Hall BJ, Doyle J, et al. Scoping the scope of a Cochrane review. Journal of Public Health. 2011; 33(1): 147150. PMid:21345890 http://dx.doi.org/10.1093/pubmed/fd r015

[27] Kelly L, St Pierre-Hansen N. So many databases, such little clarity Searching the literature for the topic aboriginal. Canadian Family Physician. 2008; 54 (11): 1572-1573. PMid:19005131

[28] Braverman IM. To see or not to see: how visual training can improve observational skills. Clinics in Dermatology. 2011; 29(3): 343346. PMid:21496744 http://dx.doi.org/10.1016/j.clinder matol.2010.08.001

[29] Klugman CM, Peel J, Beckmann-Mendez D. Art rounds: Teaching interprofessional students visual thinking strategies at one school. Academic Medicine. 2011; 86(10): 1266-1271. PMid:21869658 http://dx.doi.org/10.1097/ACM.0b013e31822c1427

[30] Jarodzka H, Balslev T, Holmqvist K, et al. Conveying clinical reasoning based on visual observation via eye-movement modelling examples. Instructional Science. 2012; 40(5): 813-827. http: //dx.doi.org/10.1007/s11251-012-9218-5
[31] Naghshineh S, Hafler JP, Miller AR, et al. Formal art observation training improves medical students' visual diagnostic skills. Journal of General Internal Medicine. 2008; 23(7): 991-997. PMid:18612730 http://dx .doi.org/10.1007/s11606-008-0667-0

[32] Pellico LH, Friedlaender L, Fennie KP. Looking is not seeing: Using art to improve observational skills. Journal of Nursing Education. 2009; 48(11): 648-653. PMid:19731892 http://dx.doi.org/10. 3928/01484834-20090828-02

[33] Grossman S, Deupi J, Leitao K. Seeing the Forest and the Trees: Increasing Nurse Practitioner Students' Observational and Mindfulness Skills. Creative nursing. 2014; 20(1): 67-72. PMid:24730194 http://dx.doi.org/10.1891/1078-4535.20.1.67

[34] Jasani SK, Saks NS. Utilizing visual art to enhance the clinical observation skills of medical students. Medical Teacher. 2013; 35(7): e1327-e1331.

[35] Shapiro J, Rucker L, Beck J. Training the clinical eye and mind: using the arts to develop medical students' observational and pattern recognition skills. Medical Education. 2006; 40(3): 263 268. PMid:16483329 http://dx.doi.org/10.1111/j.1365-2 929.2006.02389.x

[36] Carrasco M. Visual attention: The past 25 years. Vision Research 2011; 51(13): 1484-1525. PMid:21549742 http://dx.doi.org/1 $0.1016 / \mathrm{j} \cdot$ visres. 2011.04 .012

[37] Hillman KM, Bristow PJ, Chey T, et al. Duration of life-threatening antecedents prior to intensive care admission. Intensive Care Medicine. 2002; 28(11): 1629-1634. PMid:12415452 http://dx.d oi .org/10.1007/s00134-002-1496-y

[38] Gunning WT, Fors UG. Virtual patients for assessment of medical student ability to integrate clinical and laboratory data to develop differential diagnoses: comparison of results of exams with/without time constraints. Medical Teacher. 2012; 34(4): e222-e228.

[39] Richard CM, Wright RD, Ee C, et al. Effect of a concurrent auditory task on visual search performance in a driving-related image-flicker task. Human Factors: The Journal of the Human Factors and Ergonomics Society. 2002; 44(1): 108-119. http://dx.doi.org/1 $0.1518 / 0018720024494874$

[40] Fogarasi A, Szirtes G, Zsiák G, et al. Improving seizure recognition by visual reinforcement. Neurology, Psychiatry and Brain Research. 2012; 18(1): 1-7. http://dx.doi.org/10.1016/j.npbr. 2011 .10 .002

[41] Schulz CM, Schneider E, Fritz L, et al. Visual attention of anaesthetists during simulated critical incidents. British Journal of Anaesthesia. 2011; 106(6): 807-813. PMid:21474477 http://dx.doi.o $\mathrm{rg} / 10.1093 / \mathrm{bja} / \mathrm{aer} 087$

[42] Bogossian F, Cooper S, Cant R, et al. Undergraduate nursing students' performance in recognising and responding to sudden patient deterioration in high psychological fidelity simulated environments: An Australian multi-centre study. Nurse Education Today. 2014; 34(5): 691-696. PMid:24183634 http://dx.doi.org/10.1016/j.ned t. 2013.09.015

[43] Silverman BD. Physician behaviour and bedside manners: the influence of William Osler and The Johns Hopkins School of Medicine. Proceedings (Baylor University. MedicalCenter). 2012; 25(1): 58. Available from: http://www.ncbi.nlm.nih.gov/pubmed/2227 $5787 /$ 